\title{
RELATO DE EXPERIÊNCIA: CONSTRUÇÃO DE UMA HORTA HIDROPÔNICA EM AMBIENTE ESCOLAR
}

\section{Tatiane Santos ${ }^{1}$}

\section{Thayze Rochele Sabei ${ }^{2}$,}

\section{Josmaria Lopes de Morais ${ }^{3}$}

\section{INTRODUÇÃO}

Na primeira etapa da educação básica, na Educação Infantil, a questão ambiental aparece nos objetivos gerais do Referencial Curricular Nacional para Educação Infantil - RCNEI, os quais ressaltam que a criança precisa: Observar e explorar o ambiente com atitude de curiosidade, percebendo-se cada vez mais como integrante, dependente e agente transformador do meio ambiente e valorizando atitudes que contribuam para sua conservação (BRASIL, 1998).

A transformação das práticas pedagógicas no ambiente escolar, no sentido de serem reflexivas e participativas, é ainda um processo que desafia a grande maioria dos professores. Seguindo Guimarães (2004), "o modelo tradicional de ensino de transmissão de conteúdos ainda é muito forte". Com isso, transformar a teoria e os discursos em ações pedagógicas crítico-reflexivo e prático ainda é um grande obstáculo.

\footnotetext{
${ }^{1}$ Tecnóloga Ambiental, Mestranda Ciência e Tecnologia PPGCTA/UTFPR,. E-mail: thayyzze@hotmail.com

${ }^{2}$ Pedagoga, cursando especialização em Educação Ambiental UFPR-Litoral, E-mail: tathy.1001@gmail.com

${ }^{3}$ Professora do Programa de Pós Graduação em Ciência e Tecnologia Ambiental da Universidade Tecnológica Federal do Paraná. E-mail: jlmorais@utfpr.edu.br
} 
No entanto, projetos de educação ambiental para serem efetivos devem promover simultaneamente, o desenvolvimento de conhecimento, de atitudes e de habilidades necessárias à preservação e melhoria da qualidade ambiental.

Nessa perspectiva é possível utilizar, como laboratório, o metabolismo urbano e seus recursos naturais e físicos, iniciando pela escola, expandindo-se pela circunvizinhança e sucessivamente até a cidade, a região, o país, o continente e o planeta. A aprendizagem será mais efetiva se a atividade estiver adaptada às situações da vida real da cidade, ou do meio em que vivem aluno e professor (GADOTTI, 2000).

Este trabalho tem como objetivo relatar a vivência de planejar, construir e manter uma Horta Hidropônica Caseira, em ambiente escolar, utilizando materiais recicláveis. Sendo que, a educação ambiental foi o eixo central da proposta de construção de horta e o educando foi incentivado a participar de todas as etapas possibilitando ampliar seu relacionamento com o meio ambiente

Nesta perspectiva a proposta da construção e utilização de materiais recicláveis para construção de Horta visou propiciar envolvimento dos alunos através da observação, experimentação e exploração de atividades diferenciadas que possibilitaram uma melhor compreensão de conceitos relacionados com meio ambiente.

\section{OBJETIVO GERAL}

Construir de uma Horta Hidropônica Caseira utilizando materiais recicláveis, com crianças das turmas de Pré I, idade de 4 para 5 anos da Escola Municipal de Educação Infantil Helena Kolody, São José dos Pinhais

\section{OBJETIVOS ESPECÍFICOS}


Realizar um encontro com os professores de cada turma, para discutir a elaboração da atividade.

Despertar o interesse da criança para a implantação da horta através de aulas ministradas em sala com explicações sobre como funciona a horta, sua relação com meio ambiente natural, importância desses alimentos para a saúde humana, entre outros assuntos.

Possibilitar que os alunos preparem na prática seu vaso feito com garrafas Pet, plantando uma muda de hortaliça e acompanhem 0 desenvolvimento dessa planta e após aproximadamente 20 dias a levem para casa.

\section{METODOLOGIA}

O Centro Municipal de Educação Infantil Helena Kolody fica localizado no bairro Atuba, no município de Pinhais, PR e atualmente atende a 215 crianças em período integral, sendo duas turmas de maternal II (dois a três anos), três turmas de maternal III (três a quatro anos) e três turmas de pré I (quatro a cinco anos).

Foi realizado um encontro com os educadores das turmas onde foi discutida a realização da atividade de Horta Hidropônica e suas interações com os conteúdos de ensino. Nesse encontro, foi definido que os alunos envolvidos na atividade seriam das 3 turmas do Pré I, sendo um total de 84 educando. Antes da atividade de Horta, para cada turma foi realizado uma aula com conteúdos relacionados educação alimentar, questões sócio-ambientais, utilização de materiais recicláveis, exemplificando a construção de uma horta hidropônica.

Antes da atividade com os alunos, as garrafas pet foram cortadas de forma a se utilizar a parte superior para o plantio, com a tampa virada para baixo, e a parte inferior como reservatório para a água. Na montagem a parte inferior deve ficar sobreposta a inferior, de forma que possibilite seu deslocamento para a reposição da água. 
$\mathrm{Na}$ atividade prática cada criança, com o acompanhamento da educadora, montou um vaso e em seguida, realizou o plantio de uma muda. $\mathrm{O}$ local escolhido para manter os vasos foi um canteiro em frente a Escola.

Esses vasos foram observados pelos alunos por aproximadamente três semanas e, após esse período, as crianças levam as hortaliças para casa.

\section{RESULTADO}

O projeto foi realizado separadamente com as turmas 3 turmas do Pré I, cada turma com 28 alunos, totalizando 84 educandos.

Foi realizado um encontro com os professores para discutir os conhecimentos de cada um a respeito de como é realizada as atividades de construção de uma horta hidropônica, buscando fontes de referencias, de trabalhos acadêmicos para entender melhor como trabalhar essa prática com os alunos.

Em sala de aula foi trabalhado com eles a respeito dos cuidados que devemos ter com as plantas e sua importância para a conservação da vida no planeta, como ocorre a fotossíntese, como devemos conservar as florestas, a importância de uma alimentação saudável (frutas, verduras). Também foi demonstrado através de uma amostra como ficaria as mudas e explicado como funcionaria na escola.

As garrafas Pet foram cortadas de forma a se utilizar a parte superior para o plantio, com a tampa virada para baixo, e a parte inferior como reservatório para a água. A parte inferior ficará sobreposta a inferior, de forma que possibilite seu deslocamento para a reposição da água.

Os alunos foram para o espaço da horta, onde colocaram terra na parte superior (ver se tem um nome especifico) da garrafa e na sequência plantaram uma muda de hortaliça. Após o plantio, levaram o reservatório para ser preenchido com água, para poderem sobrepor a planta.

A horta ficou exposta na entrada da Escola e após vinte dias as crianças levaram uma planta para casa, para ser cultivada até o momento de ser colhida. 


\section{CONSIDERAÇÕES FINAIS}

Desde a aula inicial até a implantação da horta possibilitou aos professores trabalhar os conteúdos interdisciplinaridade, contribuindo como recurso pedagógico para serem analisados e trabalhados em sala, como a educação alimentar e questões sócio-ambientais.

Após a construção foi possível observar por 20 dias o desenvolvimento das hortaliças, e percebe-se a empolgação dos alunos, por estarem levando para suas casas seu vaso com uma planta que poderiam consumir, mostrouse que trabalhos como este de construção de uma horta pode ser um bom material didático ao ponto de desenvolver um importante papel no resgate da cultura, assim como da cidadania, e na consciência de todos os envolvidos.

Para as crianças essas atividades realizadas em um ambiente natural podem revelar os significados e as características do ambiente sendo experiências diretas, ao invés de simplesmente comunicar informação. Quando é possibilitada a participação dos alunos em práticas lúdicas e de vivências integradas a natureza a motivação, entusiasmo e entrega dos participantes aos temas propostos é facilmente observada (ANDREATTA et al. 2007).

Atividades como esta devem ser realizadas com maior freqüência nas escolas, para promover a educação ambiental de forma, mas direta e acessível aos alunos. Permitindo aos mesmos vivenciarem na prática o que se aprende na teoria.

\section{REFERENCIAS}

BRASIL, MEC/SEF. Referencial Curricular Nacional para a Educação Infantil: introdução, vol.1, Brasília, 1998.

ANDREATTA, V. KARNOPP, P. K. MACEDO, R. L. G. VITORINO, M. R. MACEDO, S. B. VENT URINI, N. O lúdico a través de dinâmicas vivenciadas na natureza contribuindo para a formação de educadores ambientais. In: Congresso Nacional de Ecoturismo, 2007, Itatiaia. Anais do Congresso Nacional de Ecoturismo. Itatiaia: Phsys, 2007 
GADOTTI, M. Perspectiva atuais da Educação. Porto Alegre: Artes Médicas, 2000

GUIMARÃES, M. A formação de educadores ambientais. Campinas: Papirus, 2004.

MEDEIROS, Herika Bastos de; MIRANDA, Antonio Carlos de; ENNES, Jacques Lages. A construção de uma Horta Hidropônica:Uma Proposta Envolvendo a Educação AmbientaL. Periódico Eletrônico Fórum Ambiental da Alta Paulista, v. 8, n. 6, 2012.

PIZZATTO, C.; BITTENCOURT, J. C. Projeto horta na escola. Revista Científica Sophia - Faculdade AVANTIS, v. 2(1): p. 37-44, 2010. 